\title{
TRGOVANJE LJUDIMA U SVRHU UKLANJANJA ORGANA NA KOSOVU
}

\author{
Fejzi Beqiri \\ Općina Bujanovac, Srbija \\ E-mail: fejzi.k.beqiri@gmail.com
}

\section{SAŽETAK}

Trgovanje ljudima problem je s kojim se međunarodne i nacionalne institucije i organizacije intenzivno bave od početka 21. stoljeća. Glavnina interesa posvećuje se trgovanju ljudima (posebice ženama i djecom) u svrhu seksualnog iskorištavanja, a druge moguće svrhe iskorištavanja ostaju relativno nepoznate. Uklanjanje organa jedna je od tih relativno neprepoznatih svrha trgovanja ljudima. Cilj je ovog rada pregled aktualnih spoznaja o trgovanju ljudima u svrhu uklanjanja organa te analiza konkretnog slučaja Medicus na Kosovu s namjerom provjere aktualnih spoznaja na konkretnom slučaju. Pregled dostupne literature pokazuje da žrtve trgovanja ljudima radi uklanjanja organa često dolaze iz nerazvijenih zemalja te se suočavaju s različitim financijskim poteškoćama, tj. žive u ekstremnom siromaštvu, što je glavna motivacija za prodaju vlastitih organa. To ih čini naročito osjetljivima za organizirane skupine koje žrtve namamljuju lažnim obećanjima o visini naknade i minimalnim zdravstvenim posljedicama te adekvatnoj postoperativnoj skrbi.

Ključne riječi: trgovanje ljudima, ljudski organi, slučaj Medicus, Kosovo

\section{UVOD}

Zahvaljujući razvoju tehnologije i znanstvenim dostignućima danas se čovjeku može znatno produžiti život. Danas, s tuđim organima na planetu žive stotine tisuća ljudi jer postoji mogućnost transplantiranja srca, jetre, bubrega, tkiva i stanica. Broj bolesnika kojima je potreban neki organ ogroman je, a darivatelja je malo (Ursić, Barić, i Umnik, 2006) jer većina ljudi ne želi da se poslije smrti njihovi organi iskoriste za spas pacijenata kojima prijeti sigurna smrt. Takva situacija dovela je do razvoja ilegalnog tržišta ljudskim organima koji su pogodni za transplantaciju.

Problem ilegalnog trgovanja ljudskim organima prepoznat je u okviru trgovanja ljudima, što od početka 21. stoljeća izaziva veliku pozornost međunarodnih organizacija i institucija.

Cilj je ovog rada pregled aktualnih spoznaja o trgovanju ljudima radi uklanjanja ljudskih organa i provjera njihove primjenjivosti u slučaju Medicus s Kosova. Za potrebe utvrđivanja aktualnih spoznaja o problemima trgovanja ljudima radi uklanjanja organa, pretražena je postojeća i dostupna literatura, dok su za potrebe analize slučaja Medicus korišteni podatci pribavljeni od Osnovnog suda u Prištini, Apelacijskog suda u Prištini i Specijalnog tužiteljstva Republike Kosovo.

Analiza je realizirana unutar dvaju glavnih tematskih područja:

1. Obilježja počinitelja, žrtava i procesa trgovanja ljudima u svrhu uklanjanja organa

2. Financijska i materijalna korist počinitelja / kriminalnih skupina. 


\section{MEĐUNARODNI, REGIONALNI I NACIONALNI OKVIRI DEFINIRANJA PROBLEMA}

Prije prikaza rezultata analize konkretnog slučaja i usporedbe elemenata tog slučaja s aktualnim međunarodnim spoznajama o tom problemu, potrebno je reći nešto o međunarodnim, regionalnim i nacionalnim okvirima definiranja problema trgovanja ljudima u svrhu uklanjanja organa. U nastavku poglavlja slijedi prikaz relevantnih međunarodnih i regionalnih dokumenata koji adresiraju taj problem te se na kraju poglavlja daju prikazi nacionalnih okvira definiranja problema u Hrvatskoj i na Kosovu.

Trgovanje ljudima u svrhu uklanjanja organa definirano je u Protokolu za sprečavanje, suzbijanje i kažnjavanje trgovanja ljudima, posebice ženama i djecom, kojim se dopunjava Konvencija Ujedinjenih naroda protiv transnacionalnog i organiziranog kriminala (United Nations Convention against Transnational Organized Crime, 2000). Tako se člankom 3. Protokola definira da „trgovanje ljudima znači vrbovanje, prijevoz, transfer, smještaj ili prihvat osoba pomoću prijetnje ili uporabe sile ili drugih oblika prinude, otmice, obmanom, prijevarom, zlouporabom ovlasti ili položaja, bespomoćnosti ili davanjem ili primanjem plaćanja ili sredstava da bi se postigla privola osobe koja ima kontrolu nad drugom osobom, u svrhu izrabljivanja. Iskorištavanje će uključivati, u najmanju ruku, iskorištavanje prostitucije drugih ili drukčijih oblika seksualnog iskorištavanja, prisilni rad ili usluge, ropstvo ili odnose slične ropstvu, podčinjavanje ili odstranjivanje organa." Ta definicija sadrži tri bitna elementa koji trebaju biti prisutni da bi se konkretan slučaj mogao razumjeti kao trgovanje ljudima (kada su u pitanju djeca, potrebno je utvrđivanje postojanja svega dvaju elemenata). Ta tri elementa su: radnja, sredstvo (tj. način) i iskorištavanje. Značajno je istaknuti i to da se $u$ istom članku navodi da je pristanak žrtve na namjeravano iskorištavanje irelevantan ako je upotrijebljeno bilo koje od nabrojenih sredstava (načina).

Dakle, u smislu Protokola, trgovanje ljudima podrazumijeva poduzimanje određenih činjenja uz primjenu određenih sredstava ili načina činjenja u svrhu iskorištavanja žrtve trgovanja ljudima.

Za uspostavljanje međunarodnih standarda u borbi protiv trgovanja ljudima značajna je i Konvencija Vijeća Europe o suzbijanju trgovanja ljudima (CoE, Convention on Action against Traffickingin Human Beings, 2005). U njoj se trgovanje ljudima kvalificira kao kršenje ljudskih prava i napad na dostojanstvo i integritet čovjeka. Njezini su primarni ciljevi osiguranje poštovanja prava žrtava i njihova zaštita, borba protiv trgovanja ljudima i unapređenje međunarodne suradnje u suzbijanju trgovanja ljudima. Konvencija Vijeća Europe prihvaća definiciju trgovanja ljudima iz Protokola za sprečavanje, suzbijanje i kažnjavanje trgovanja ljudima, posebice ženama i djecom. Osim toga, za ovu temu relevantni su i neki drugi dokumenti: Konvencija Vijeća Europe o zaštiti ljudskih prava i dostojanstva ljudskog bića u pogledu primjene biologije i medicine: Konvencije o ljudskim pravima i biomedicini iz 2000. godine ( $\mathrm{CoE}$, Convention for the protection of Human Rights and Dignity of the Human Being with regard to the Application of Biology and Medicine: Convention on Human Rights and Biomedicine, 1997) i Dodatni protokol uz Europsku konvenciju o zaštiti ljudskih prava i dostojanstva ljudskog bića u pogledu primjene biologije i medicine, u vezi s presađivanjem organa i tkiva ljudskog podrijetla iz 2002. godine. Protokol prvi put izravno zabranjuje novčane dobiti i raspolaganja dijelom ljudskog tijela, kao i dodatak naknade donatorima za razumne troškove. Ta činjenica određena je člankom 21. poglavlja VI (CoE, Additional Protocol 
to the Convention on Human Rights and Biomedicine, concerning Transplantation of Organs and Tissues of Human Origin, 2002).

Svjetska zdravstvena organizacija pozvala je zemlje članice "da poduzmu mjere zaštite najsiromašnijih i najranjivijih skupina od transplantacijskog turizma i prodaje organa i tkiva, posvećujući pažnju širem problemu međunarodne kupoprodaje ljudskih tkiva i organa" (WHO, 2010). Što se tiče principa u vezi s transplantacijom organa također su ponovljena i razrađena i u Istanbulskoj deklaraciji iz 2008. Istanbulska deklaracija, u skladu s rezolucijom 44.25 Skupštine Svjetske zdravstvene organizacije, poziva na zabranu presađivanja organa u svrhu transplantacijskog komercijalizma, kupoprodaje organa ili transplantacijskog turizma. Prema Istanbulskoj deklaraciji takva politika ili praksa definirana je kao politika ili praksa kojom se organ tretira kao roba koja se prodaje i kupuje ili se koristi za materijalni dobitak (Declaration of Istanbul on Organ Trafficking and Transplant Tourism, 2008).

U pravu Europske unije oduzimanje organa prepoznato je kao pojavni oblik trgovanja ljudima tek Direktivom 2011/36/EU o suzbijanju i borbi protiv trgovanja ljudima i zaštiti žrtava iz 2011. godine, gdje je predviđeno, kao jedan od mogućih oblika iskorištavanja, odnosno konstitutivni element, trgovanje ljudima. Izraz odstranjivanje organa određen je kao oblik trgovanja ljudima kojima se ozbiljno narušava ljudsko dostojanstvo i fizički integritet. Direktivom su dodatno određene posebne radnje trgovanja ljudima koje uključuju i razmjenu ili prijenos kontrole nad osobama koje su predmet trgovanja (Directive 2011/36/Eu of the European Parliament and of the Council, 2011).

Gotovo svaka država u svijetu suočava se s problemom trgovanja ljudima, odnosno trgovanjem ljudima u svrhu uklanjanja organa ili nezakonite transplantacije. Negdje je taj problem reguliran zakonskim odredbama, pravilnicima i drugim podzakonskim aktima, a negdje nije reguliran u dovoljnoj mjeri ili uopće nije reguliran. Tako, primjerice, Republika Hrvatska ima nacionalni kaznenopravni okvir u suzbijanju trgovanja ljudima. U članku 106. Kaznenog zakona (NN, 125/11, 126/19) sankcionirano je kazneno djelo: „Trgovanje ljudima“. Kao jedna od svrha iskorištavanja navodi se i uzimanje dijelova tijela osobe koja je žrtva tog kaznenog djela. U članku 107. Kaznenog zakona sankcionirano je kazneno djelo: "Trgovanje dijelovima ljudskog tijela i ljudskim zametcima”, a u članku 182. „Nedozvoljeno uzimanje i presađivanje dijelova ljudskog tijela“. Osim toga, u Hrvatskoj je usvojen Zakon o presađivanju ljudskih organa u svrhu liječenja (NN, 144/12), Pravilnik o uvjetima u pogledu prostora, radnika, medicinsko-tehničke opreme, kvalitete i sigurnosti za obavljanje djelatnosti uzimanja i presađivanja organa (NN, 54/13); Pravilnik o načinu vođenja medicinske dokumentacije te osiguranju sljedivosti svih pribavljenih, dodijeljenih i presađenih ljudskih organa (NN, 54/13); Pravilnik o načinu procjene obilježja preminulog darivatelja i organa za presađivanje (NN, 62/13); i Pravilnik o standardima kvalitete i sigurnosti organa za presađivanje (NN, 62/13).

Republika Kosovo također ima nacionalni kazneno-pravni okvir u odnosu na suzbijanje trgovanja ljudima. U članku 171. Kaznenog zakona (Glava XV) kaznena djela protiv čovječnosti i vrijednosti koje štiti međunarodno pravo (Službeni list Republike Kosova, 2012) i Zakon o sprečavanju i borbi protiv trgovanja ljudima i zaštiti žrtava trgovanja ljudima (Službeni list Republike Kosova, 2013). Nažalost, Kosovo, kao novonastala država, još nije usvojila Zakon o transplantaciji organa zbog čega nedostaju podzakonski akti koji uređuju ovo područje. Stoga se može reći da je Kosovo 
jedina država od svih europskih i regionalnih zemalja koja nije regulirala darivanje i presađivanje organa posebnim zakonom i podzakonskim aktima.

\section{ZNAČAJKE PRAVNOG SUSTAVA NAKON RATA NA KOSOVU}

Za bolje razumijevanje konteksta trgovanja ljudima zbog uklanjanja ljudskih organa na Kosovu, potrebno je bar sažeto prikazati temeljne značajke ustroja i funkcioniranja Kosova nakon rata.

Prilikom ulaska vojnih međunarodnih mirovnih snaga (u daljnjem tekstu KFOR) i početkom operacije Misija privremene uprave Ujedinjenih nacija na Kosovu (u daljnjem tekstu UNMIK), Kosovo je zatečeno devastirano u gospodarskom, političkom, pravnom, sigurnosnom i socijalnom smislu. Međutim, stanovnici su bili vrlo uvjereni da će se Kosovo uskoro oporaviti u svim institucijskim segmentima.

Misija UNMIK-a bila je vrlo heterogena i vrlo složena da bi se osiguralo učinkovito upravljanje odgovornostima koje su joj povjerene (Hajdari, 2014). Povrh toga, postojao je i Specijalni predstavnik glavnog tajnika (u daljnjem tekstu SPGS). On je obavljao sve vlasti i predstavljao konačnu, zakonodavnu, izvršnu i sudsku vlast na Kosovu (Bajrami, 2002). Sve poluge vlasti bile su u istim rukama, a osim toga, odluke koje je donio Predstavnik glavnog tajnika, lokalno stanovništvo nije moglo preispitivati. Način djelovanja SPGS-a često je bio netransparentan, ali lokalno stanovništvo nije imalo pravo razriješiti ga (Caplan, 2005; prema Lemay-Hébert, 2009).

Člankom 1. Uredbe br. 1999/24 od 12.12.1999. predviđeno je da su zakoni, koji se primjenjuju na Kosovu tijekom tog razdoblja, sljedeći (Uredba, 1999):

a) Uredbe koje objavljuje Specijalni predstavnik Generalnog sekretara zajedno s dolje navedenim dopunskim pravnim instrumentima ${ }^{1} \mathrm{i}$

b) Zakon koji je bio na snazi na Kosovu dana 22. ožujka 1989.

Čak i nakon usvajanja Ustavnog okvira Kosova i stvaranja privremene samouprave, velik broj pitanja ostao je u isključivoj nadležnosti SPGS-a, kao što su: zaštita prava zajednica, raspodjela Skupštine, usvajanje budžeta Kosova, monetarna politika, obnašanje konačne kontrole nad carinskom službom, imenovanje i razrješenje sudaca i tužitelja, imenovanje i razrješenje međunarodnih sudaca, odlučivanje iz određenih područja u inozemstvu (Bajrami, 2002).

\footnotetext{
1 U slučaju spora, uredbe i dolje navedeni dopunski pravni instrumenti imaju prednost.

1.2 Ako u postupku odlučivanja nadležni sud ili tijelo vlasti ili pravno lice utvrdi da pravna osnova nije uređena zakonima opisanim u članu 1.1. ove Uredbe, ali je uređena nekim drugim zakonom koji je na snazi na Kosovu poslije 22. ožujka 1989. godine, sud, tijelo vlasti ili pravno lice primijenit će propise koji su na snazi poslije tog datuma.

1.3 Prilikom obavljanja svojih funkcija, sva lica koja obavljaju svoje javne dužnosti ili rade u javnim službama pridržavaju se međunarodno priznatih standarda o ljudskim pravima, koji se naročito ogledaju u sljedećim dokumentima: a) Opća deklaracija o ljudskim pravima od 10. prosinca 1948.

b) Europska konvencija o zaštiti ljudskih prava i osnovnih sloboda od 4. studenoga 1950. zajedno s Protokolom;

c) Međunarodni sporazum o građanskim i političkim pravima od 16. prosinca 1966. godine zajedno s Protokolom

d) Međunarodni sporazum o ekonomskim, društvenim i kulturnim pravima od 16. prosinca 1966.

e) Konvencija o eliminaciji svih oblika rasne diskriminacije od 21. prosinca 1965.

f) Konvencija o eliminaciji svih oblika diskriminacija žena od 17. prosinca 1979.

g) Konvencija protiv torture i ostalih okrutnih, nehumanih i ponižavajućih postupaka ili oblika kažnjavanja od 17. prosinca 1984.

h) Međunarodna konvencija o pravima djeteta od 20. prosinca 1989.

1.4 Nijedno lice koje obavlja javne dužnosti ili radi u javnim službama na Kosovu ne smije sprovoditi diskriminaciju ni prema komu na osnovu spola, rase, boje, jezika, vjere, političkog ili drugog mišljenja, prirodnog, etničkog ili društvenog podrijetla u vezi s nacionalnom zajednicom, imovinom, na osnovi rođenja ili drugog statusa. Tijekom krivičnog postupka, okrivljeni može koristiti najpovoljnije odredbe Kaznenog zakona koji je bio na snazi na Kosovu od 22. ožujka 1989. godine do dana donošenja ove Uredbe.

1.5 Ukida se smrtna kazna.
} 
Dakle, za vrijeme UNMIK-a, Kosovo je imalo paraliziran pravni sustav, dok su se istovremeno primjenjivala tri različita pravna sustava u istom društvu:

- donesene Uredbe UNMIK-a

—Zakon koji je bio na snazi na Kosovu dana 22. ožujka 1989.

—Zakoni i drugi podzakonski akti koje su usvojile određene institucije Kosova.

Naravno da je Kosovo, kao novonastala zemlja tijekom tranzicije u velikoj mjeri, kao što je već rečeno, bilo paralizirano u zakonodavnom sustavu, što je ujedno i bilo glavnim uzrokom nerazvijanja u gospodarskoj sferi i nestabilnosti u političkom smislu itd. U takvim uvjetima itekako je postojao prostor za djelovanje organiziranih kriminalnih skupina.

Kako ističe Singer (Singer, 1998; prema Bačić, 1999) pojava organiziranog kriminala u velikoj je mjeri odraz gospodarskih, političkih i društvenih prilika u određenoj zemlji, ali i u društvu u cjelini. Posebno je to verificirano u zemljama u tranziciji. Uvijek se taj kriminalitet prilagođava, racionalno vođen i usmjeravan, specifičnim prilikama određenih tržišta robe i usluga, kao i općenitog stanja i problema u gospodarstvima.

\section{SLUČAJ MEDICUS - ZNAČAJKE KRIMINALNE GRUPE}

Prema Optužnici i Presudi Osnovnog i Apelacijskog suda u Prištini, organizirana kriminalna skupina bila je strukturirana skupina koja se sastojala od nekoliko osoba, s fleksibilnom unutrašnjom organizacijskom strukturom i planom, koja je postojala najmanje nekoliko mjeseci tijekom 2008. godine i nije slučajno formirana za izravno činjenje jednog kaznenog djela, već je formirana radi činjenja jednoga ili više teških kaznih djela na redovnim osnovama, posebno trgovanja ljudima radi stjecanja izravne ili neizravne financijske ili druge materijalne koristi, pomoću procesa uklanjanja organa (bubrega) i transplantacije tih organa u tijelo primatelja (Presuda osnovnog suda u Prištini br. P 309 / 10 P 340 / 10 od 29 travnja 2013 godine). Na takav je način dobro organizirana kriminalna skupina uključivala mnoge povezane aktivnosti, kao što su: regrutiranje, transport, transfer, logistika, plaćanje, dostupnost objekta (Klinika Medicus), dostupnost obučenih liječnika i vođenje specijaliziranih medicinskih postupaka (transplantacija bubrega).

S obzirom na navedene činjenice i način djelovanja, pokazuje se koliko je složen delikt trgovanja ljudima radi uklanjanja organa. U sudskom postupku bio je velik broj suđenja, svjedočenja, dokumenata, postupaka, zahtjeva za međunarodnu pravnu pomoć, sve u namjeri da počinitelji budu kažnjeni zasluženom kaznom. Specijalni tužitelj EULEX-a (Misija vladavine prava Europske unije na Kosovu) Joanthan Rathel u završnoj je riječi zbrojio da je u slučaju Medicus svjedočilo 78 svjedoka, održane su 103 sjednice konvertirane u 525 sati suđenja, 21 svjedočenje odvijalo se putem videolinkova, pet vještačenja, 29 dosjea s tisućama dokumenata i 30 zahtjeva za međunarodnu pravnu pomoć.

Činjenica da se ljudskim organom može trgovati samo ako ga je prethodno odstranila profesionalna osoba, u konkretnom slučaju stručno medicinsko osoblje - liječnik ili kirurg, daje poseban značaj toj vrsti delikta. Trgovanje ljudskim organima nemoguće je bez sudjelovanja profesionalaca 
liječničke profesije koji su članovi organizirane kriminalne skupine. Također, valja imati na umu da su mjesto obavljanja bile u većini slučajeva privatne klinike.

U slučaju Medicusa samo jedan od optuženih nije bio liječnik (Presuda Osnovnog suda u Prištini br. P 309 / 10 P 340 / 10 od 29. travnja 2013 godine).

\section{PROFIL BROKERA}

Međunarodni mešetari / tržišni posrednici posjeduju posebne vještine jer većinom svoje usluge oglašavaju putem interneta. Tehnologija danas olakšava kriminalne aktivnosti te omogućava organizaciju svih logističkih potreba - hotele, obroke, avionske karte, centre za presađivanje i online kirurške usluge. Npr. u slučaju Medicus darivatelji su bili regrutirani putem interneta ili putem novinskih oglasa. Oglasi su bili na ruskom jeziku u Izraelu, te je navedena i "stručna osoba - broker" za kontaktiranje, kao i broj telefona. Brokeri su također izrađivali krvne testove svim darivateljima; poslije prve analize, živi darivatelji su čekali od 1 do 2 mjeseca dok bi bio pronađen primatelj, a nakon toga bi bili pozivani i obaviješteni da je pronađena odgovarajuća osoba za daljnji postupak, i pravovremeno bi dobili brokerove upute (Presuda Osnovnog suda u Prištini br. P 309 / 10 P 340 / 10 od 29. travnja 2013 godine).

Darivatelji ili primatelji izravno su putovali iz svojih država u Istanbul, jedno od glavnih mjesta djelovanja brokera koji najviše sudjeluju u toj kriminalnoj aktivnosti. Darivatelji su podvrgavani daljnjim medicinskim testovima da bi se potvrdila njihova prikladnost darivatelja bubrega. Osim toga, brokeri ili njihovi asistenti, imali su obvezu osigurati logističke aranžmane - hotele, obroke, avionske karte za darivatelja da bi postigli kontrolu nad njima i tako onemoguće bilo kakav kontakt s drugim osobama. Darivateljima ili primateljima prije napuštanja Istanbula često bi se upućivalo pozivno pismo u kojem bi bilo navedeno da dolaze u Medicus zbog nespecifična liječenja, s namjerom da olakšavaju ulazak na Kosovo u slučaju sumnje ili mogućeg ispitivanja kosovske granične policije. Također, u slučaju ispitivanja granične policije upućeni su odgovarati općenito - reći da posjećuju rođake ili im pokazati navedeno pismo koje je izdala Klinika Medicus te da nikako ne spominju transplantaciju bubrega. Iz Istanbula bi darivatelje ili primatelje pratili brokeri ili neki od liječnika, tako da bi oni putovali zajedno preko službenih graničnih prijelaza u Kliniku Medicus na Kosovu ili u rijetkim slučajeva, kada su putovali sami darivatelji ili primatelji, u prištinskoj zračnoj luci. Tada bi se susretali s nekim bliskim suradnikom koji bi nosio pismo s njegovim imenom. Potom ih se dovodilo u kliniku koja je bila udaljena od 40 minuta do sat vremena od zračne luke u Prištini (Presuda Osnovnog suda u Prištini br. P 309 / 10 P 340 / 10 od 29. travnja 2013. godine).

„Darivatelj - svjedok A. K. regrutiran je u Istanbulu. Učinio je to posrednik - broker, koji ga je uvjerio da će dobiti 20000 USD za bubreg, poslije toga ponuđeno mu je 10000 USD u zamjenu za bubreg, ali nakon operacije primio je 8000 USD, i obećan mu je ostatak novca samo ako regrutira druge darivatelje bubrega. Na kraju, plaćeno je 500 USD kao dug, ali isti posrednik J. zaprijetio mu je da šuti ili će trpjeti ozbiljne posljedice. Osim toga, u zdravstvenom smislu pretrpio je znatnu fizičku i psihičku traumu i njegovo se medicinsko stanje pogoršalo nakon operacije zbog lošeg funkcioniranja preostalog bubrega. Imao je poslijeoperacijskih komplikacija" (Presuda Apelacijskog suda u Prištini, br. PAKR 52/14 od 6. studenoga 2015. godine). 
Članovi te organizirane kriminalne skupine imali su za cilj širenje svojih aktivnosti, uporabom sile ili drugih oblika nasilja, odnosno otimanjem, prijevarom ili obmanom te su željeli postići kontrolu nad darivateljima, s namjerom da postanu lokalnim regruterima koji će pronalaziti ili identificirati stvarne prodavatelje / dobavljače organa. Znači, brokeri odrađuju strateške odluke za mreže, uključujući i odabir ciljane populacije za žrtve donatore i odabir lokalnih brokera. Međunarodni posrednici obično su jedina kontinuirana kontaktna točka s primateljima organa. Kao takvi, ti posrednici kontroliraju tijek financiranja koji financira druge dijelove mreža (OSCE, 2013).

Očigledno je da organizirana kriminalna skupina u slučaju Medicus generalno, tijekom procesa od oglašavanja, prvog kontakta s darivateljima i primateljima, tijekom transplantacije bubrega do povrataka u zemlje podrijetla, nije dopuštala da primatelji i darivatelji preuzimaju neku radnju sami; oni su bili praćeni u svakom trenutku i bili su upućeni kako se ponašati prema nadležnim zakonodavnim tijelima. Kupci - primatelji organa na crnom tržištu, često realiziraju svoje ilegalne transplantacije putem posrednika za organe. Posrednici mogu biti iz svih društvenih slojeva, od organiziranog kriminala do liječnika (Crepelle, 2016). U svrhu ilustriranja uloge brokera u kriminalnoj skupini na Slici 1. donosimo shematski prikaz mreže trgovine ljudima u svrhu uklanjanja organa.

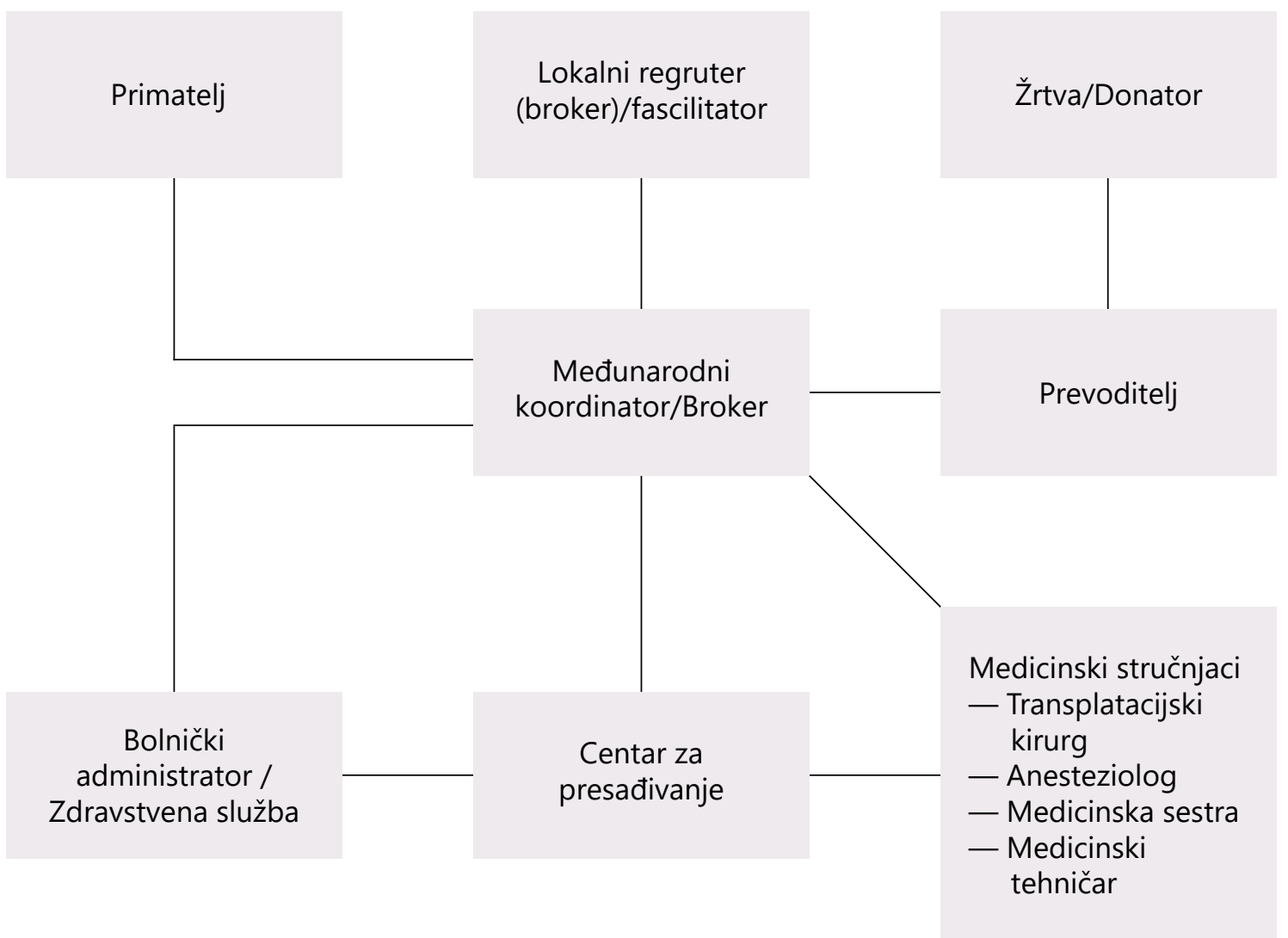

Slika 1. Mreža trgovanja ljudima u svrhu uklanjanja organa (OSCE, 2013) 


\section{PROFIL ŽRTVE}

Kao i kod svakog drugog pojavnog oblika transnacionalnog organiziranog trgovanja (trgovanje drogama, trgovanje oružjem, trgovanje automobilima, kreditiranjem, trgovanje djecom, prostitucijom, i sl.) tako i se i kod trgovanja ljudima u svrhu uklanjanja organa događa naizmjenično kretanje s jednog na drugi kraj svijeta, iz siromašnijih u bogatije krajeve. Na globalnoj razini zemlja izvoznica organa najčešće je Indija, gdje se organi od lokalnih donatora redovito presađuju strancima. Prema nekim autorima, crna tržišta organa u Indiji još uvijek postoje i ponovno se javljaju u Indiji (Shimazono, 2007). Pad stranih primatelja u Indiji popraćen je porastom broja stranih primatelja u drugim zemljama kao što su: Pakistan, Filipini, Kina, Egipat, Bolivija, Brazil, Irak, Izrael, Iran, Republika Moldavija, Nigerija, Rumunjska, Peru i Turska (Aronowitz i Isitman, 2013).

U slučaju Medicus, darivatelji bubrega koji su svjedočili na suđenju bili su strani državljani iz siromašnih zemalja, uglavnom iz istočne Europe i osobno su doživljavali ozbiljne financijske teškoće, što ih je činilo pogodnim za viktimizaciju. Zemlje, izvoznice organa, u konkretnom slučaju bile su: Turska, Bjelorusija, Kazahstan, Ukrajina, Rusija, Moldavija, Izrael i druge zemlje koje nisu utvrđene (Presuda Osnovnog suda u Prištini br. P 309 / 10 P 340 / 10 od 29. travnja 2013. godine).

Svi darivatelji, "regrutirani" iz stranih zemalja, prevezeni su na Kosovo preko Istanbula, prebačeni iz zračne luke Prištine u Kliniku Medicus, primljeni u Kliniku i sklonjeni na Klinici sve do uklanjanja bubrega. Turska je u tom slučaju bila tranzitna država trgovanja ljudskim organima jer su svi darivatelji i primatelji iz svojih država, odnosno država podrijetla, putovali za Istanbul, a potom za Kosovo koje je bilo država destinacije. Darivatelji su u klinici ostajali od tri do pet dana, a tijekom boravka za njih su se brinuli liječnici i medicinske sestre, no, nažalost, darivateljima nije pruženo adekvatno liječenje. To je evidentno na temelju poslijetransplantacijskih komplikacija jer je većina njih tražila medicinsku pomoć u svojim državama (Presuda Apelacijskog suda u Prištini br. PAKR 52/14 od 6. studenoga 2015. godine).

Uobičajena je praksa da se, kada poslijetransplantacijski postupak prođe bez komplikacija, otpust kući može očekivati najranije deset dana poslije transplantacije. U bolesnika kod kojih se funkcija bubrega sporije uspostavlja otpust se realizira obično dva do tri tjedna poslije transplantacije (Hrvačević, 2004). To su neka opća pravila koja treba poštovati jer kod 1/3 bolesnika razdoblje oporavka bubrežne funkcije traje tri tjedna, iako je kod nekih bolesnika taj period i duži (Hrvačević, 2004).

Općenito govoreći, darivatelji su pretrpjeli znatnu fizičku i psihološku traumu. Njihovo medicinsko stanje pogoršavalo se nakon operacije zbog lošeg funkcioniranja preostalog bubrega i poslijeoperacijskih komplikacija s obzirom da nisu imali odgovarajuću medicinsku i psihosocijalnu skrb u vrijeme operacije, odnosno donacije i nakon nje.

Zaštićeni svjedok A. D. izjavio je: „prvo jutro nakon operacije u blizini njegova kreveta ležala je starija muška osoba koja nije mogla govoriti, ali poslije tri dana, kada je bio u stanju govoriti, rekao mu je da je zahvalan što je bio njezin darivatelj. Taj razgovor bio je na engleskom jeziku. Koliko se sjećao ta je osoba bila u dobi 60 - 70 godina, podrijetlom iz Izraela, ali živjela je u New Yorku, gdje je imala svoj biznis" (Presuda Apelacijskog suda u Prištini br. PAKR 52/14 od 6. studenoga 2015. godine). 
Gunnarson i Lundin (2015) navode sljedeća sociodemografska obilježja davatelja organa:

— Osobe koje imaju nisku razinu obrazovanja ili su nepismeni;

— Osobe koje su siromašne, imigranti, izbjeglice;

- Osobe kod kojih ima nedostatka osnovnoga medicinskog znanja i nisu svjesni mogućih zdravstvenih posljedica uklanjanja organa (bubrega);

—Žrtve pripadaju starosnoj grupi od 18 do 30 godina, uglavnom su muškarci;

—Žrtve dolaze iz zemalja u kojima nedostaje zakonodavni sustav za efikasnu zabranu trgovine ljudima te iz zemalja gdje postoji visoka razina korupcije.

I u slučaju Medicus prisutna su slična obilježja davatelja organa u smislu starosti i spola. Prema podatcima iz sudskih spisa u slučaju Medicusa 80 \% davatelja organa bili su muškarci i 20 \% žene. Što se tiče starosti, najmlađi davatelj imao je svega 20 godina života.

Što se tiče organa, koji su najčešće objekt crnog tržišta, vjeruje se da bubrezi čine 75 \% crnog tržišta. Stručnjaci vjeruju da porast oboljenja - poput dijabetesa, visokoga krvnog tlaka i srčanih problema - potiče trgovinu. U slučaju Medicus bubrezi čine 100 \% organa koji su bili objekt crnog tržišta, odnosno transplantacije.

Na temelju prethodno navedenih obilježja može se zaključiti da davatelji organa, kao i u ostalim slučajevima trgovanja ljudima, često dolaze iz nerazvijenih zemalja, suočeni su s različitim financijskim problemima, odnosno žive u ekstremnom siromaštvu. Također, često su i žrtve prijevare ili obmane jer im organizirane kriminalne skupine daju lažna obećanja o velikim novcima, a zapravo, dobivaju jako malo.

\section{PROFIL PRIMATELJA ORGANA}

Potrebe za organima su u porastu širom svijeta, a liste čekanja duge. Prema procjeni OSCE-a, 4100 pacijenata je umrlo dok je službeno stavljeno na liste čekanja tijekom 2013. godine u EU, u 28 država članica Europske unije (odnosno 3780 i 5500 pacijenata umrlo je na listama čekanja tijekom 2012. i 2011.). Ako se uključe i pacijenti iz Islanda, Norveške i Turske, može se procijeniti da je brojka povećana na 6000 pacijenata koji su umrli dok su službeno stavljeni na liste čekanja tijekom $2013^{2}$. Prosječno vrijeme čekanja na transplantaciju bubrega u Europi je tri godine, u Njemačkoj čak pet, a procijenjeno je da je 2010. godine, za transplantaciju organa vrijeme čekanja bilo do 10 godina (Meyer, 2006). U slučaju Medicus, primatelji bubrega imali su više od deset godina problema s bubrezima, većina od njih bili su na dijalizi i transplantacija bubrega bila im je prijeko potrebna za daljnji život, bili su u mogućnosti platiti velike iznose novca da spase svoje živote ili živote članova uže obitelji. Uglavnom, bili su regrutirani u Izraelu i plaćali su posrednicima (brokerima) / trgovcima ljudskim organima. Uplaćivali su velike iznose (od 70.000 eura do 108.000 američkih dolara), samo da u što kraćem roku dobiju bubreg. Također, oni su svjedočili da su iznos platili u gotovini, i to na način da su jedan dio novca platili odmah nakon dogovora s brokerom, a drugi dio platili

2 https://doi.org/10.31299/ksi.28.1.4 
su u Istanbulu, prije operacije (Presuda Osnovnog suda u Prištini br. P 309 / 10 P 340 / 10 od 29. travnja 2013. godine).

Jedno od bitnih obilježja primatelja je da dolaze iz znatno razvijenih država od država davatelja organa. U trgovanju ljudima u svrhu uklanjanja organa važnu ulogu ima Izrael, koji se donedavno navodio kao zemlja uvoza organa ili zemlja visoke potražnje (Policy Department, 2015). U slučaju Medicusa utvrđeno je da se trgovanje ljudima u svrhu uklanjanja organa uglavnom odvijalo od siromašnih do bogatih zemalja. Osim toga, važna uloga Izraela utvrđena je i u tom slučaju. Kupci - primatelji uglavnom su dolazili iz Izraela, ali bilo je i onih koji su došli iz Ukrajine, Turske, Poljske, Kanade, Njemačke, kao i mnogih drugih neobjavljenih lokacija (Presuda Osnovnog suda u Prištini br. P 309 / 10 P 340 / 10 od 29. travnja 2013. godine).

Starost primatelja organa, prema studiji koja je napravljena s 22 pacijenta - primatelja organa (10 iz Makedonije i Kosova, 7 iz Nizozemske i 5 iz Švedske) prikazana je u Tablici 1. (Ambgsheer, 2007).

Tablica 1. Starost primatelja organa (Ambagtsheer, 2007)

\begin{tabular}{|c|c|c|}
\hline Starost & Broj primatelja & $\%$ \\
\hline $25-35$ & 4 & 18,2 \\
\hline $36-45$ & 4 & 18,2 \\
\hline $46-55$ & 8 & 36,4 \\
\hline $56-65$ & 6 & 27,3 \\
\hline
\end{tabular}

Prema Tablici 1. jasno je vidljivo da je najveći broj primatelja organa bio u dobi 46 - 55 godina. Prosječna starost primatelja organa na globalnoj razini je 48,1 godina, što je u skladu s upravo navedenim podatcima (Policy Department, 2015).

Podatci iz sudskog spisa u slučaju Medicus pokazuju da su $100 \%$ primatelja organa bili muškarci, najstariji primatelj bio je star 72 godine i najmlađi primatelj organa bio je star 55 godina. Svi ti primatelji organa svjedočili su tijekom procesa suđenja pred Osnovnim sudom u Prištini (Presuda Osnovnog suda u Prištini br. P 309 / 10 P 340 / 10 od 29. travnja 2013 godine).

Primatelji organa imaju sljedeća zajednička obilježja:

1. Kronični bolesnici

2. Bogati

3. Žive u razvijenim državama

4. Obrazovaniji u odnosu na davatelje

5. Muškog roda itd.

Ako usporedimo profil darivatelja i primatelja organa jasno je da imaju dijametralno različita opća sociodemografska obilježja (prikazano u Slici 2.). Ono što im je zajedničko, interes je za rješavanjem bitnih životnih problema - kod davatelja organa radi se o financijskom interesu koji rješava značajne ekonomske probleme davatelja i njegove obitelji, a kod primatelja se radi o zdravstvenom interesu. 


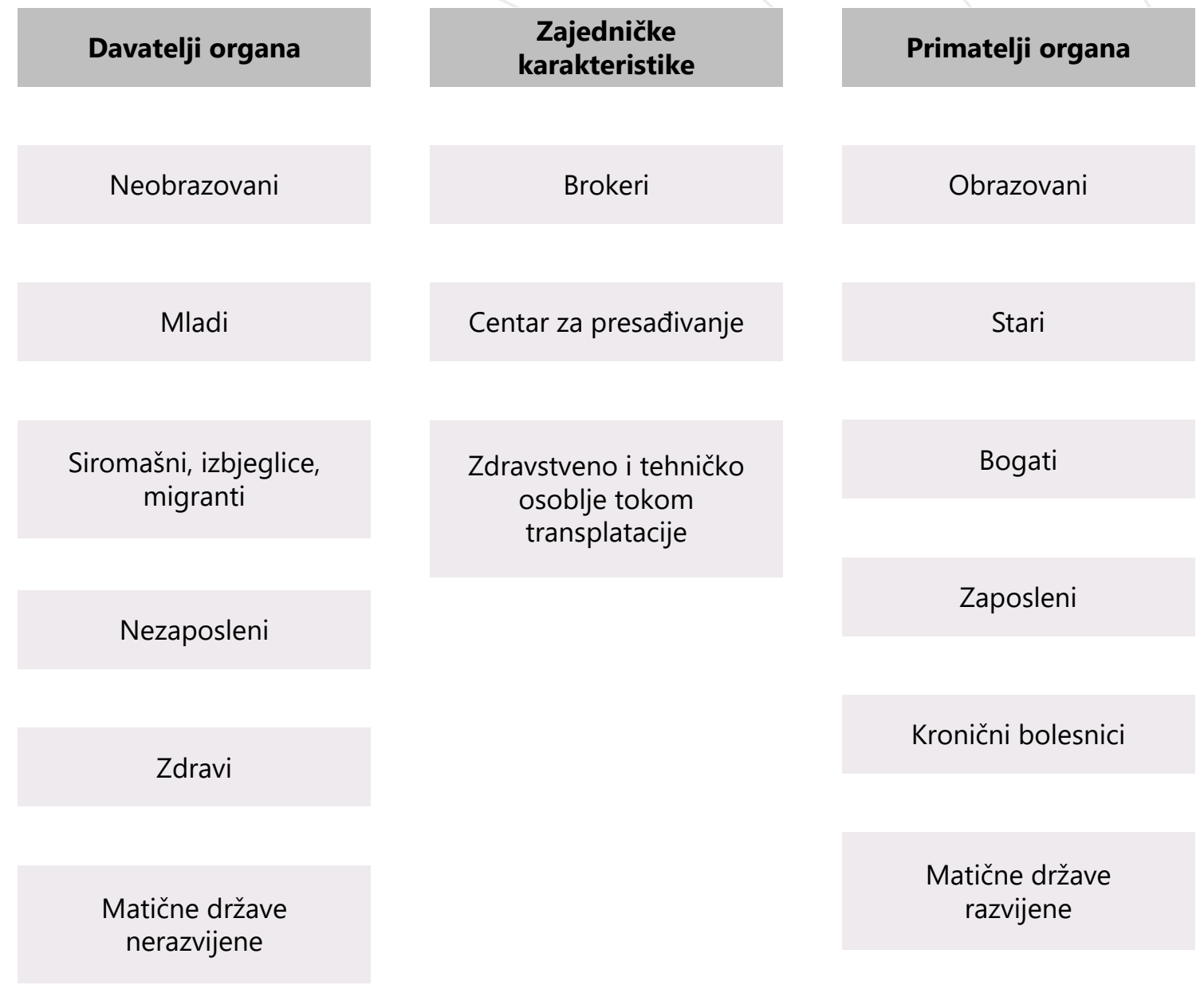

Slika 2. Razlike i dodirne točke primatelja i davatelja organa

Iz slike je razvidno da je interes davatelja i primatelja jedina dodirna točka između jednih i drugih, tj. točka na kojoj se sreću teški bolesnici s jedne strane i ekstremno siromašni s druge strane. Brokeri, tj. posrednici su ti koji prepoznaju potrebe jedne i druge strane i u svoju korist organiziraju zadovoljavanje potreba jednih i drugih.

\section{FINANCIJSKA I MATERIJALNA KORIST POČINITELJA / KRIMINALNIH SKUPINA}

Već je ranije navedeno da se u situaciji kupoprodaje ljudskih organa na crnom tržištu širom svijeta suočavaju dvije različite vrste ljudi - s jedne strane osobe koje dolaze iz razvijenih zemalja, s vrlo dobrim prihodima i s druge strane beznadni ljudi iz trećeg svijeta koji žive u ekstremnom siromaštvu, a među njima su brokeri, odnosno kriminalne skupine.

Trgovanje organima, zajedno s trgovanjem droge, ljudima, oružjem, dijamantima, zlatom i naftom, postaju predmetom ilegalne industrije s prihodom od više milijardi dolara u svijetu (Beširević i sur., 2012). Organizacija Global Financial Integrity, (GFI) sa sjedištem u SAD-u, u svom izvještaju iz 2011. godine (Haken, 2011), predstavila je procjenu da se trgovanjem ljudskim organima može generirati nezakonita zarada od 600 milijuna USD do 1,2 milijardi USD na godišnjoj razini. 
Ta procjena ne uključuje procjene za transplantaciju srca, pluća ili gušterače, za koje podatci nisu dostupni (Haken, 2011). Podatci koje je predstavila Global Financial Integrity (GFI) u svom izvještaju iz 2017. godine pokazuju da postoji veliki broj ilegalnih transplantacija na godišnjoj razini širom svijeta i s prevelikim cijenama na crnom tržištu.

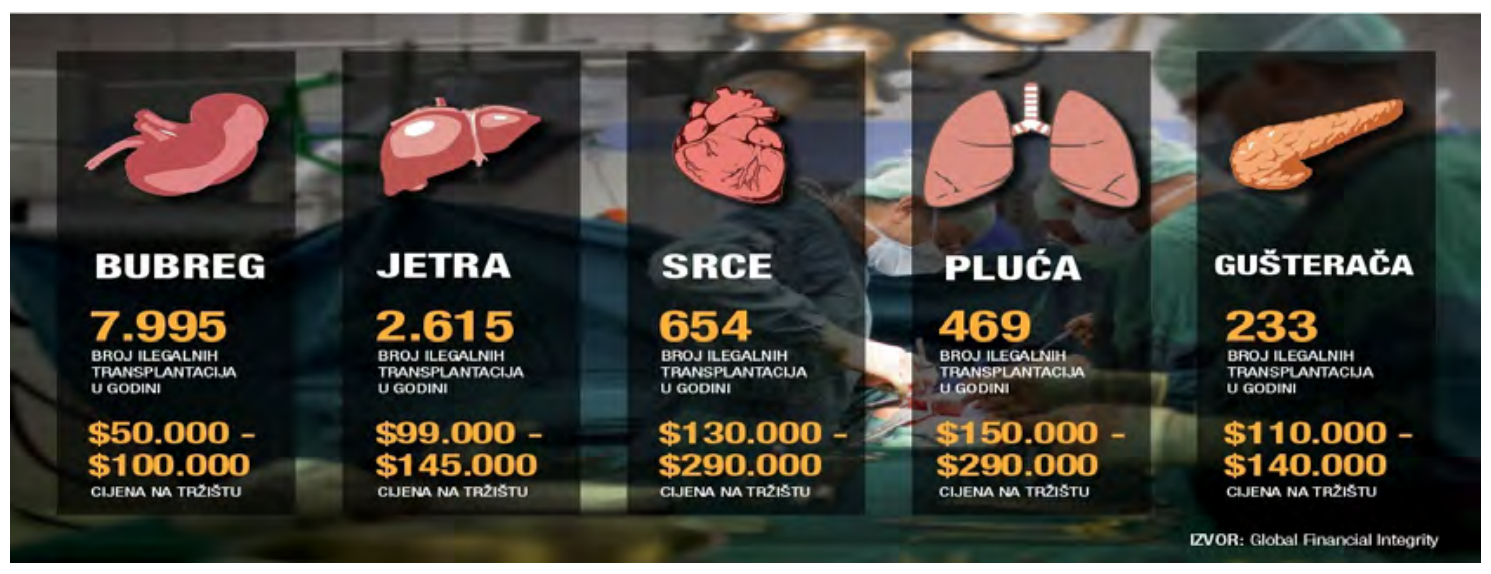

Slika 3. Maloprodajne cijene organa (GFI prema May, 2017).

Prema podatcima Organizacije Global Financial Integrity (GFI) za 2017. godinu, od ilegalnog trgovanja organima generira se od 840 milijuna do 1,7 milijardi dolara godišnje. Ta procjena odnosi se na ilegalnu prodaju pet najprodavanijih organa: bubrega, jetre, srca, pluća i gušterače. Postoji ogromna razlika u iznosu novca koji davatelj organa plati i iznosa koji primatelji dobivaju. Tako, naprimjer, cijena bubrega u razvijenim zemljama iznosi 20000 USD, a u zemljama u razvoju 3000 USD - razlika je veća od 500 \% (May, 2017). Ako usporedimo podatke predstavljene u izvještaju za 2011. godinu i podatke koji su predstavljeni u izvještaju za 2017. godine (Global Financial Integrity), jasno je da su kriminalne organizirane skupine ogromno povećavale svoje prihode od 2011. godine do 2017. godine, a to podrazumijeva da one svake godine povećavaju obim i dinamiku djelovanja širem svijeta.

I u slučaju Medicus, organizirana kriminalna skupina stekla je financijsku ili drugu materijalnu korist na sljedeće gotovinske isplate.

1. Od zaštićenog svjedoka "T3" u iznosu od 100000 američkih dolara

2. Od zaštićenog svjedoka "T4" u iznosu od 70000 eura

3. Od zaštićenog svjedoka M2 u iznosu od 108000 američkih dolara

4. Od zaštićenog svjedoka A1 u iznosu od 79000 eura

5. Od T. S. u iznosu od 25000 eura

6. Od R. F. u iznosu od 80000 eura

7. Od zaštićenog svjedoka "M1" u iznosu od 77000 eura 
8. Od zaštićenog svjedoka "T2" u iznosu od 90000 eura (Presuda Apelacijskog suda u Prištini br. PAKR 52/14 od 6. studenoga 2015. godine).

Žrtve trgovanja dobivale su niske novčane iznose u odnosu na uplate primatelja. Darivateljima bubrega organizirana kriminalna skupina gotovinske isplate obavila je na sljedeći način:

1. Zaštićenom svjedoku "W2" obećano je 15000 USD u zamjenu za bubreg, ali je dobila samo 12000 USD

2. Zaštićeni svjedok "W1" dobio je iznos od 12000 USD

3. Zaštićenom svjedoku "W3"obećan je iznos od 10000 eura, plaćeno je 10000 USD u eurima 8100 ili 8200.

4. Zaštićenom svjedoku "PM" obećan je iznos od 30000 USD, plaćeno je 1000 USD

5. Zaštićenom svjedoku "DS", obećan je iznos od 20000 USD plaćeno je 6000 USD

6. Zaštićenom svjedoku "AK" obećan je iznos od 10000 USD. Međutim, nakon operacije primio je 8000 USD i obećan mu je ostatak od 500 USD kao dug, ali posrednik mu je zaprijetio da šuti ili će trpjeti ozbiljne posljedice.

7. Zaštićeni svjedok "Y. A", dobio je iznos od 20000 USD (Presuda Apelacijskog suda u Prištini br. PAKR 52/14 od 6. studenoga 2015. godine).

U razdoblju od 1. ožujka 2008. godine do 4. studenog 2008. godine organizirana kriminalna skupina u slučaju Medicus od primatelja organa dobila je iznos od $208000,00 \$$ i 420 000,00€= $589480,00 €$ (petsto osamdeset devet tisuća četiristo osamdeset eura), a darivateljima su platili $69500,00 \$=56295,00 €$ (pedeset šest tisuća dvjesto devedeset pet eura), tako da je navedena organizirana skupina u tom razdoblju stvorila dobit oko $947 \%$. Također, u ovom slučaju, žrtve su bile prevarene u ukupnom iznosu od $30658,00 €$ jer je obećano $86953,00 €$, a zapravo su dobili svega $56295,00 €$. Usporedbom s podatcima Organizacije Global Financial Integrity, organizirana kriminalna skupina u slučaju Medicus, stvorila je profit od 447 \% više. Iz svega naprijed navedenog može se zaključiti da su financijsko stanje ili materijalna korist bili važniji za organiziranu kriminalnu grupu od brige o zdravlju darivatelja i primatelja organa.

\section{ZAKLJUČNA RAZMATRANJA I PREPORUKE}

Trgovanje ljudima u svrhu uklanjanja organa krši ljudsko dostojanstvo i pravo na život te predstavlja ozbiljnu prijetnju za javno zdravstvo. Kaznene politike protiv te pojave trebaju biti stroge jer posljedice takvoga kaznenog djela mogu biti značajne za žrtvu, mogu izazvati smrt ili ozbiljno oštećenje fizičkoga ili mentalnog zdravlja. Ta negativna društvena pojava širi se velikom dinamikom s izvanrednim prednostima za kriminalne skupine zbog vrlo niska rizika za kazneni progon počinitelja kaznenog djela.

Trgovanje ljudima kao moderni oblik ropstva izaziva veliku pozornost međunarodne zajednice. O tome svjedoči znatan broj konvencija, protokola, preporuka i drugih dokumenata donesenih u svrhu suzbijanja te pojave (Kovčo Vukadin i Jelenić, 2003). Tako se u preambuli Deklaracije iz 
Istanbula navodi da je transplantacija organa jedno od medicinskih čuda XX. stoljeća i da je kao takva produžila i poboljšala živote stotina tisuća bolesnika širom svijeta. Mnogi sjajni znanstveni i klinički uspjesi predanih zdravstvenih profesionalaca, kao i bezbrojni akti milosrđa davatelja organa i njihovih obitelji, učinili su transplantaciju ne samo terapijom koja spašava život nego i svijetlim simbolom ljudske solidarnosti (Declaration of Istanbul on Organ Trafficking and Transplant Tourism, 2008).

To znanstveno dostignuće, odnosno ovo ostvarenje, u sjenci je brojnih ilegalnih kupoprodaja organa, brojnih putovanja radi transplantacije; ljudska bića su se koristila, a i danas se koriste kao izvori organa u raznovrsnim klinikama - bolesni, a bogati ljudi iz bogatih zemalja putuju u inozemstvo da bi kupovali organe od siromašnih beznadnih ljudi.

I u slučaju Medicus potvrđene su upravo navedene činjenice jer su s jedne strane bili beznadni siromašni ljudi s financijskim teškoćama, bez nade i mogućnosti drugoga izbora, koji su pretrpjeli znatnu fizičku i psihološku traumu i bili prevareni, dok su s druge strane bili beznadno bolesni ljudi, bogati iz bogatih zemalja, koji su se nadali daljnjem životu, a između njih je postojao posrednik (broker) odnosno kriminalna organizirana skupina. Osim toga, u trgovanju ljudima u svrhu uklanjanja organa, kao i u ostalim slučajevima širom svijeta i u slučaju trgovanja ljudima u svrhu uklanjanja organa na Kosovu, u slučaju Medicus, profili brokera, darivatelja, primatelja, modus operandi organiziranog kriminala otprilike je sličan. Ono što razlikuje slučaj Medicus od ostalih slučajeva je financijski profit. Tim radom utvrđeno je da je organizirana kriminalna skupina u slučaju Medicus, prema podatcima koji su uzeti iz Presude Osnovnog i Apelacijskog suda u Prištini, ostvarila 447 \% više profita u usporedbi s ostalim organiziranim kriminalnim mrežama tijekom godine.

Temeljem provedenog prikaza i analize, a u svrhu unapređenja prakse transplantacije i suzbijanja trgovanja ljudima radi uklanjanja organa i drugih zlouporaba organiziranih kriminalnih skupina, za Kosovo se mogu dati sljedeće preporuke:

— državne institucije Republike Kosova trebaju kreirati politiku ili standarde za borbu protiv trgovanja ljudima u svrhu uklanjanja organa na nacionalnoj razini;

- Republika Kosovo treba usvojiti zakonodavni okvir koji regulira pitanje transplantacije organa;

- Da sustav "opt out” ili sustav pretpostavljene suglasnosti treba prihvatiti Skupština Republike Kosovo. To znači da uzimanje organa od umrlih osoba u načelu nije zabranjeno, već dopušteno. Time se povećava broj potencijalnih darivatelja jer u njih spadaju i oni koji se uopće nisu izjasnili. Zakoni o transplantaciji većine zemalja Europske unije prihvaćaju taj model;

- Da vlasti države ne prepuštaju problem trgovanja ljudima u svrhu uklanjanja organa i ilegalne aktivnosti samo medijima i istraživačkom novinarstvu, već da se angažiraju akcijama više zemalja i njihovom suradnjom u domeni zdravstva, pravosuđa i unutarnjih poslova radi sprečavanja te negativne društvene pojave. 


\section{LITERATURA}

Ambagtsheer, F. (2017). Organ Trade. PhD Thesis. Netherlands: Erasmus University Rotterdam.

Aronowitz, A.A. \& Isitman, E. (2013). Trafficking of human beings for the purpose of organ removal: are (international) legal instruments effective measures to eradicate the practice? Groningen Journal of International Law, 1(2), 73-90.

Bačić, F. (1999). Neki kaznenopravni aspekti problematike organiziranog kriminaliteta. Hrvatski ljetopis za kazneno pravo I praksu, 6(1), 37 -54.

Bajrami, A. (2002). E drejta e Kosovës në Tranzicion. Prishtinë.

Beširević, V., Codreanu, N., Demény, E., Florea, G.T. \& Sándor, J. (2012). Improving the effectiveness of the organ trade prohibition in Europe: recommendations. Chisinau: EULOD Project. Dostupno na: http://hottproject.com/userfiles/Publicaties/ENGIMPROVINGTHEEFFECTIVENESSOFTHEORGANTRADEPROHIBITIONINEUROPE.pdf

Council of Europe (1997). Convention for the protection of Human Rights and Dignity of the Human Being with regard to the Application of Biology and Medicine: Convention on Human Rights and Biomedicine, No. 164.

Council of Europe (2002). Additional Protocol to the Convention on Human Rights and Biomedicine, concerning Transplantation of Organs and Tissues of Human Origin. CETS No. 186.

Council of Europe (2005). Council of Europe Convention on Action against Trafficking in Human Beings, No. 197.

Crepelle, A. (2016). A Market for human organs: an ethical solution to the organ shortage. Indiana Health Law Review, 13(1), 18-79. http://dx.doi.org/10.18060/3911.0012

Directive 2011/36/EU of the European Parliament And of the Council of 5 April 2011 on preventing and combating trafficking in human beings and protecting its victims, and replacing Council Framework Decision 2002/629/JHA

Gunnarson, M. \& Lundin, S. (2015). The complexities of victimhood: insights from the organ trade. Somatechnics, 5(1), 32-51. http://dx.doi.org/10.3366/soma.

Hajdari, A. (2014). Disa nga sfidat dhe problemet me të cilat u përball funksionimi sistemi të drejtësisë penale në Kosovën e pasluftës, Revista studimore shkencore-buletini shkencor, 1, 193- 203.

Haken, J. (2011). Transnational crime in the Developing World. Washington DC: Global Financial In-

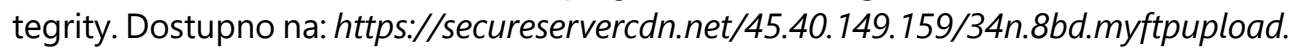
com/wp-content/uploads/2014/05/gfi_transnational_crime_high-res.pdf

Hrvačević, R. (2004). Život sa presađenim bubregom: vodič za bolesnike. Beograd. Dostupno na: http://intertim.net/content/intertim/Transplatacija\%20bubrega\%20-\%20knjiga.pdf

https://ec.europa.eu/health//sites/health/files/blood_tissues_organs/docs/ev_20141126_factsfigures_ en.pdf

Kazneni zakon. Narodne novine, 125/11, 144/12, 56/15, 61/15, 101/17, 118/18, 126/19.

Kazneni zakonik Republike Kosove. Službeni list Republike Kosova, 04/L-82/ 20 travanj 2012.

Kovčo Vukadin, I. i Jelenić, D. (2003). Trgovanje ljudima: kriminološki i kaznenopravni aspekt. Hrvatski ljetopis za kazneno pravo i praksu, 10(2), 665-718. 
Lemay-Hébert, N. (2009). State building from the outside-in: UNMIK and its paradox. Journal of Public and International Affairs, 20, 65-86.

May, C. (2017). Transnational crime and the developing world. Washington DC: Global Financial Integrity. Dostupno na: https://secureservercdn.net/45.40.149.159/34n.8bd.myftpupload. com/wp-content/uploads/2017/03/Transnational_Crime-final.pdf

Meyer, S. (2006). Trafficking in human organs in Europe. European Journal of Crime, Criminal Law and Criminal Justice, 14(2), 208-229.

Optužnica Specijalnog tužilaštva Republike Kosovo (STRK) PPS. 02/09 od 22. ožujak 2013.

OSCE Office of the Special Representative and Co-ordinator for Combating Trafficking in Human Beings (2013). Trafficking in human beings for the purpose of organ removal in the OSCE region: analysis and findings. Occasional Paper Series no. 6. Vienna: OSCE. Dostupno na: $h$ ttps://www.osce.org/secretariat/103393?download=true

Policy Department Directorate-General for External Policies (2015). Trafficking in human organs. Belgium: EU

Pravilnik o standardima kvalitete i sigurnosti organa za presađivanje. Narodne novine, 62/13.

Pravilnik o načinu procjene obilježja preminulog darivatelja i organa za presađivanje. Narodne novine, 62/13.

Pravilnik o načinu vođenja medicinske dokumentacije te osiguranju sljedivosti svih pribavljenih, dodijeljenih i presađenih ljudskih organa. Narodne novine, 54/13.

Pravilnik o uvjetima u pogledu prostora, radnika, medicinsko-tehničke opreme, kvalitete i sigurnosti za obavljanje djelatnosti uzimanja i presađivanja organa. Narodne novine, 54/13.

Presuda Apelacionog suda u Prištinu br. PAKR 52/14 od 06 Studeni 2015. godine

Presuda osnovnog suda u Prištini br. P 309 / 10 P 340 / 10 od 29 travnja 2013 godine

Shimazono, Y. (2007). The state of the international organ trade: a provisional picture based on integration of available information. Bulletin of the World Health Organization, 85(12), 955-962. doi: 10.2471/BLT.06.039370

The transplantation society \& International society of nephrology (2008). Declaration of Istanbul on Organ Trafficking and Transplant Tourism

United Nations Convention against Transnational Organized Crime, General Assembly resolution $55 / 25$ of (15 November 2000)

Ursić, A., Barić, M. i Umnik, T. (2006). Trgovanje ljudskim organima. Kriminologija \& socijalna integracija, 14(1), 101-112.

WHO, World Health Assembly. Resolution WHA63.22 on Guiding principles on human cell, tissue and organ transplantation, 2010;

Zakon o sprečavanju i borbi protiv trgovine ljudima i zaštiti žrtava trgovine ljudima. Službeni list Republike Kosova, 04/l-218/31. srpanj 2013.

Zakon o presađivanju ljudskih organa u svrhu liječenja. Narodne novine, 144/12. 
Fejzi Beqiri

Municipality Bujanovac, Serbia

\title{
TRAFFICKING IN HUMAN BEINGS FOR PURPOSE OF ORGAN REMOVAL IN KOSOVO
}

\begin{abstract}
Trafficking in human beings has been an issue that international and national institutions and organizations have been dealing with intensively since the beginning of the 21 st century. The majority of interest is devoted to trafficking in human beings (especially women and children) for the purpose of sexual exploitation whereas other possible purposes of exploitation remain relatively unrecognized. Organ removal is one of those relatively unrecognized purposes of human trafficking. The aim of this paper is to review current knowledge on trafficking in human beings for the purpose of organ removal and to analyze the specific Medicus case in Kosovo in order to verify current knowledge about a specific case. A review of the available literature shows that victims of organ trafficking for the purpose of organ removal often come from underdeveloped countries and face various financial difficulties, i.e. they live in extreme poverty and this motivates them to sell their own organs. This makes them particularly vulnerable to organized groups who lure victims with false promises of compensation and minimal health consequences, as well as adequate postoperative care.
\end{abstract}

Keywords: human trafficking, human organs, Medicus case, Kosovo 